\title{
Identification of "Ryan Virus" as an Amoeba of the Genus Hartmannella
}

\author{
J. A. ARMSTRONG,* M.B., M.SC. ; MARGUERITE S. PEREIRA, † M.D.
}

[With Special Plate]

A recent paper (Pereira, et al., 1966) reported the isolation in Britain of several strains of an antibiotic-resistant infective agent that caused unusual cytopathic effects when inoculated into cell cultures. The new agent was evidently recoverable from the respiratory tract in certain patients, mostly young children, with illnesses of varying severity but with fever and respiratory symptoms as common features. Primary isolations were made in HeLa or monkey-kidney-cell cultures, and the agent was successfully subcultured in a wide range of cell types. Nuclear changes with eosinophilic inclusions developed within 24 hours in inoculated cultures, followed in two to three days by disintegration of the cell sheet. The effect was suppressed by 5-fluoro-deox; uridine ; however, it was not possible to separate infectivity from cell debris. It was concluded that the responsible agent was a virus, firmly cell-associated and perhaps related to the varicella-cytomegalovirus subgroup of the herpes viruses. It was provisionally called Ryan virus. For further characterization of the agent, cell cultures and a number of normal and inoculated organ cultures of human embryo trachea were passed to the Laboratory of Cytopathology, National Institute for Medical Research, for electron microscopy and cytological study. This has revealed the presence of a protozoal cell-type in all specimens inoculated with the Ryan agent; the findings, as detailed below, suggest that the cytopathic changes previously reported are attributable to an amoeba of the genus Hartmannella.

\section{Methods}

Cell Cultures.-Monolayer cultures were prepared in small tubes with HeLa cells and with primary freshly trypsinized human-embryo-kidney cells. Fragments of human embryo trachea were cultured in small plastic dishes, as described by Hoorn and Tyrrell (1965). To all cultures 100 units of penicillin and $100 \mu \mathrm{g}$. of streptomycin $/ \mathrm{ml}$. were added.

Inocula.-All the Ryan strains were obtained by inoculation of cell cultures with nose, throat, or bronchial swabs from patients. For the present investigation the strain Ryan 1, which had been isolated in HeLa cultures, was used initially for inoculation of the monolayers. Because of likely contamination with HeLa-cell mycoplasmas, later studies were done with an early passage of Ryan 3, a strain isolated in primary monkey-kidney cells and maintained in primary humanembryo-kidney cultures.

Normal and infected cultures of HeLa and human-embryokidney cells were prepared for electron microscopy one and two days after inoculation of infective material. Fixation was in phosphate-buffered $1 \%$ osmium tetroxide, or $2.5 \%$ glutaraldehyde with osmium post-fixation. Specimens were embedded in Epikote expoxy resin, and thin sections were stained with lead citrate and uranyl acetate. Cover-slips from representative tubes in each group were Bouin-fixed and stained with haematoxylin and eosin. Tracheal organ cultures were fixed at intervals up to four days after inoculation, the

- National Institute for Medical Research, Mill Hill, London.

t Virus Refcrence Laboratory, Central Public Health Laboratory, Colinda!c, London. method used being saturated mercuric chloride with $4 \%$ acetic acid, embedded in paraffin and sectioned serially for light microscopy.

\section{Results}

Electron microscopy revealed large areas in the inoculated $\mathrm{HeLa}$ and human-embryo-kidney cultures showing obvious changes of a degenerative nature at the fine structural level, corresponding to confluent areas of cytopathic effect, as previously described (Pereira et al., 1966) in the corresponding stained monolayers. Cell damage was more severe and more widespread after two days than in the specimens taken 24 hours after inoculation. It consisted in clumping and margination of nuclear chromatin, swelling or rupture of the mitochondria and endoplasmic reticulum, and eventual fragmentation of the cells. A notable feature of the least-affected cells was the limitation of changes to the nucleus, particularly to the nucleolus. The latter was enlarged, irregular in form, and showed a peculiar redistribution and dispersal of components that are intimately combined in the nucleoli of normal cells. Affected nucleoli showed a pale, mainly granular central zone and one or more peripheral caps of fibrillar material having high electron density; at more advanced stages there was almost complete separation of the two components, leading to fragmentation of the nucleolus. In other respects the cell was often still quite normal in appearance. Primary nucleolar alterations of this kind are unusual, but have been reported previously as a response to treatment of cells with a small number of cytotoxic compounds which are thought to interfere with protein and nucleic acid synthesis.

Electron microscopy of $\mathrm{HeLa}$ and human-embryo-kidney cells showing all stages of alteration after inoculation with Ryan agent disclosed no sign of virus-like particles in the nucleus, in the cytoplasm, or extracellularly. An unexpected finding, however, was the presence alongside HeLa or humanembryo-kidney cells in the inoculated cultures of scattered atypical or foreign cells, which appeared to be of a nonmammalian type. This was first noted in human-embryokidney cultures showing advanced cytopathic effect, but was soon confirmed by further examination of all inoculated specimens. No comparable cell type was found in the uninoculated control cultures. The foreign cells were smaller than HeLa and human-embryo-kidney cells; they possessed a small round nucleus with a relatively large central nucleolus and a peripheral concentration of chromatin. The mitochondria were small, rounded, and filled with interlacing tubular cristae ; they resembled the mitochondria of certain protozoal species (Vickerman, 1962 ; Tokuyasu and Scherbaum, 1965), in marked contrast to the elongated mitochondria with transverse plate-like cristae that occur in typical mammalian cells. There were numerous cytoplasmic vacuoles, of ten forming part of a complex system of interconnecting canaliculi. Some of these contained what appeared to be ingested cell debris; and in the HeLa cultures, though not in human-embryo-kidney cultures, some of the vacuolated cells also contained clusters of membrane-limited micro-organisms of the mycoplasma type (Hummeler et al., 1965). Occasionally mycoplasmas were also 
identifiable extracellularly, adhering to the surface of $\mathrm{HeLa}$ cells.

Recognition of foreign cells in the cultures by electron microscopy prompted careful reassessment of the corresponding stained monolayers. Amoeboid cells were at once found to be invariably present in monolayers inoculated with the Ryan agent (Special Plate, Figs. 1 and 2): they were consistently absent from the uninoculated controls. These cells were most numerous in cultures showing marked cytopathic effect ; but unless examined with an oil-immersion lens they could be readily mistaken for fragments of cell debris, which were also present, and their existence could thus be overlooked by an unsuspecting observer.

On morphological grounds it is possible to identify the contaminant cells as trophozoites of the free-living soil amoeba Hartmannella castellanii, alternatively termed Acanthamoeba sp. (Volkonsky, 1931; Adam, 1964). Having an average diameter of about $14 \mu$, the cells were mostly polygonal with one or more rounded pseudopodia and a number of smaller surface projections of a spiky nature; elongated forms with a somewhat curved profile were also quite common. The cytoplasm was granular and vacuolated, and a small but welldefined nucleus was an invariable feature (Fig. 2). It measured about $3 \mu$ across and contained a heavily staining nucleolus of about $1.6 \mu$. One or more amoebae were often closely related to individual HeLa or human-embryo-kidney cells : in some such cases the mammalian cells showed nuclear changes of the kind previously interpreted as suggestive of the viral infection-that is, altered nucleoli, eosinophilic inclusions, and clumped chromatin.

In monolayers examined two days after inoculation few HeLa or human embryo-kidney cells remained intact and the culture consisted mainly of amoebae interspersed with cell debris. Undoubtedly it is this stage that was represented in Fig. 1 of the original report on Ryan isolates (Pereira et al., 1966). Final confirmation of the occurrence of amoebae in the inoculated cell cultures came from close microscopical inspection of living bottle cultures. Motile cells were detectable, moving slowly but continuously over the cell sheet. Each amoeba had a contractile vacuole, with a periodicity of about two minutes.

Histological sections of the tracheal organ cultures showed progressive destruction of the ciliated epithelial layer in the specimens inoculated with Ryan agents. Scattered amoebae were present in the connective-tissue planes under the epithelium, and around the cartilaginous plate. A small number of typical hartmannellid cysts (Volkonsky, 1931 ; Adam, 1964) were found along with trophozoites in the organ cultures. On the other hand, cysts could not be identified with certainty in the stained monolayer cultures.

\section{Discussion}

The regular finding of Hartmannella castellanii in cultures inoculated with Ryan agent, and its absence from corresponding controls, raises the obvious question whether Ryan agent can be identified as an amoeba. This possibility was not considered in the original account ; in fact, however, it is wholly consistent with the properties described. Thus serial transfer of Ryan isolates was readily achieved in tissue cultures; but attempts to separate infectivity from all cellular material were unsuccessful, leading to the hypothesis of an intimately cell-associated virus. Pathogenicity for mice on intraperitoneal and intracerebral inoculation, ether sensitivity, inhibition by 5-fluorodeoxuridine, and failure to grow in bacteriological culture media are all consistent with a free-living pathogenic amoeba. Evidence of filterability, gained from one out of many attempts, could well have been an accidental occurrence.
There is little information on the nature of cytopathic changes produced by amoebae in cell cultures. From the present experience with Hartmannella it seems that frank degeneration of HeLa or human-embryo-kidney cells may be preceded by development of eosinophilic nuclear inclusions, and by a reorganization of nucleolar fine structure similar to that caused by the antibiotics actinomycin-D and mitomycin-C (Reynolds et al., 1964 ; Lapis and Bernhard, 1965), also by the carcinogen 4-nitroquinoline $N$-oxide (Reynolds et al., 1964) and by pyrrolizidine alkaloids (Svoboda and Soga, 1966). These various substances evidently have in common the capacity to interfere with protein and nucleic acid synthesis. Actinomycin-D additionally gives rise to nuclear inclusions. So far as we are aware there is no direct evidence at present for the production of antibiotics or cytotoxic factors by freeliving amoebae. Ray (1951) observed that hartmannellid soil amoebae caused -agglutination of certain bacteria before ingesting them, but the mechanism was uncertain.

In the present study the additional finding of mycoplasmalike organisms was confined to the HeLa-cell cultures. Mycoplasmas are known to occur frequently as inapparent contaminants of HeLa-cell lines, and their presence in this instance was evidently unrelated to the cytopathic effect; it is probably only to be expected that scavenging amoebae would ingest mycoplasmas, together with fragments of mammalian cell debris.

The significance of the isolation of hartmannellid amoebae from clinical specimens has still to be determined. Their occurrence as apparently spontaneous contaminants of primary monkey-kidney-cell cultures was first reported several years ago (Jahnes et al., 1957). A similar finding by Culbertson et al. (1958) led to a clear demonstration of the pathogenicity of Hartmannella (Acanthamoeba) species in mice and monkeys, with particular reference to inoculation by the nasal route (Culbertson et al., 1959 ; Culbertson, 1961). In two further isolations of these protozoa in tissue cultures (Chi et al., 1959 ; Wang and Feldman, 1961) the cultures had been inoculated with material from pharyngeal swabs, mainly from children; the circumstances suggested that amoebae could have originated from the human nasopharynx, but this was thought to require further study.

Since the report on Ryan isolates (Pereira et al., 1966) additional strains have been recovered in three more laboratories in Britain, from a further six patients with respiratory illness. In each of the earlier isolations the agent was recovered in only one out of three inoculated culture tubes; and although control cultures were consistently negative the possibility of airborne contamination, or inherently infected cultures, cannot be entirely ruled out. In one of the new cases, however, amoebae were recovered in all of three different inoculated cell types, and were absent from the rest of the same batch of tissue cultures. This strongly suggests that the amoebae in this case were derived from the human respiratory tract, and reinforces the supposition that earlier Ryan isolates had a similar origin.

In future it is hoped that earlier recognition of hartmannellid amoebae in inoculated cultures may lead to more definite information on this point by allowing for repeated isolations with the same specimen or patient, and for closer correlation with the clinical picture. Some indication of a pathogenic role for these amoebae in man is provided by an interesting report of Acanthamoeba sp. in brain sections from four fatal cases of pyogenic meningitis in South Australia (Fowler and Carter, 1965). The organisms were found mainly in the region of the olfactory bulbs, suggesting the nose as a possible portal of entry. Three very similar cases have been encountered in the United States (Butt, 1966), in two of which amoebae were recognized in the cerebrospinal fluid before death. For the present, however, the evidence for hartmannellid amoebae having an aetiological role in human disease, except perhaps rarely, is scant and very largely circumstantial. 


\section{Summary}

Evidence is presented that a cytopathic agent isolated from human nose, throat, and bronchial swabs, and termed "Ryan virus" is in fact an amoeba of the genus Hartmannella. Detection of a protozoal cell-type by electron microscopy led to the recognition of typical trophozoites and cysts of this freeliving soil amoeba in inoculated tissue cultures. Details are given of cytopathic effects due to the amoebae, involving primarily the nuclei in cell cultures.

It is probable that amoebae do occur in the nasopharynx in some patients with respiratory illness, and they should not necessarily be regarded as laboratory contaminants. Their clinical significance and pathogenicity for man are at present conjectural.

We are indebted to our colleague Dr. D. C. Warhurst for help in identification of the amoebae, which he was able to grow readily, with encystment, on agar plates inoculated with killed Aerobacter aerogens. We are grateful to Dr. Janet Niven for helpful advice and documentation. Our thanks are also due to Dr. W. F. Lane, Dr. M. H. Hambling, and Dr. Suzanne Clarke, of the Public Health Laboratories at Bedford, Leeds, and Bristol, respectively, for sending us their recently isolated strains. Photomicrographs were made by Mr. F. Wanless.

\section{REFERENCES}

Adam, K. M. G. (1964). F. Protozool., 11, 423.

Butt, C. G. (1966). New Engl. 7. Med., 274, 1473.

Chi, L., Vogel, J. E., and Shelokov, A. (1959). Science, 130, 1763.

Chi, L., Vogel, J. E., and Shelokov, A. (1959). Science

- Smith, J. W., Cohen, H. K., and Minner, J. R. (1959). Amer. 7. Path., 35, 185.'

Fow and Minner, J. R. (1958). Science, 127, 1506.

Fowler, M., and Carter, R. F. (1965). Brit. med. F., 2, 740.

Hoorn, B., and Tyrrell, D. A. J. (1965). Brit. F. exp. Path., 46, 109. Hummeler, K., Armstrong, D., and Tomassini, N. (1965). F. Bact., 90.

Jahnes, W. G., Fullmer, H. M., and Li, C. P. (1957). Proc. Soc. $\exp$. Biol. (N.Y.), 96, 484 .

Lapis, K., and Bernhard, W. (1965). Cancer Res., 25, 628.
Pereira, M. S., Marsden, H. B., Corbitt, G., and Tobin, J. O'H. (1966). Brit. med. $\%$., 1, 130 .

Brit. med. F., 1, 130.

Reynolds, R. C., Montgomery, P.' O'B., and Hughes, B. (1964). Cancer Res., $24,1269$.

Svoboda, D., and Soga, J. (1966). Amer. F. Path., 48, 347.

Tokuyasu, K., and Scherbaum, O. H. (1965). \%. Cell Biol., 27, 67.

Vickerman, K. (1962). Exp. Cell Res., 26, 497.

Volkonsky, M. (1931). Arch. Zool. exp. gén., 72, 317.

Wang, S. S., and Feldman, H. A. (1961). Antimicrob. Ag. Chemother., i. 50 .

\section{Medical Memoranda}

\section{Haemolysis in Typhoid Fever in Children with G-6-PD Deficiency}

\author{
Brit. med. F., 1967, 1, 214-215
}

Reports in the literature on haemolysis as a complication of typhoid fever are few, and such as do exist stress its rarity (Batty Shaw, 1951; McFadzean and Choa, 1953). Similarly, documentation of infection in general as a cause of haemolysis in glucose-6-phosphate-dehydrogenase (G-6-PD) deficient individuals is sparse (Beutler, 1965).

\section{Clinical Material}

The five children reported on were among a total of 26 children in hospital for typhoid during the years 1962-5. Their ages range from 3 to 13 years. Data on the patients with haemolytic anaemia are summarized in the Table.

Increased urinary urobilinogen was found in all patients and haemoglobinuria in Case 1. There was no evidence of external blood loss in any case. The peripheral blood picture was normocytic and normochromic. G-6-PD deficiency was found in all cases, first on a screening test according to the method of Bernstein (1962) and then on quantitative estimation of reduced glutathione by the method of Beutler (1957). Blood culture grew Salmonella typhi in all five cases.

Case 5 is especially instructive, as this patient had a second haemolytic episode owing to a relapse of the infection during hospitalization, and so this case is reported in detail.

\section{CASE 5}

The sister of Case 2, aged 8 years, was admitted because of a high temperature for 10 days accompanied by diarrhoea and some vomiting. Although she was known to be deficient in G-6-PD from estimation of the enzyme at the time of her brother's illness, she was given sulphadiazine for the first three days of her illness, and then chloramphenicol until admission to hospital. Pallor was noticed by her mother on the sixth day of the illness.

On admission her haemoglobin was $6.4 \mathrm{~g} . / 100 \mathrm{ml}$., leucocytes $7,900 /$ c.mm., and reticulocytes $0.8 \%$. Blood cultures for typhoid were negative, as was the Widal test. The peripheral blood picture was normochromic and normocytic, the direct Coombs test negative, and erythrocyte osmotic fragility normal. Total serum bilirubin was $1.2 \mathrm{mg} . / 100 \mathrm{ml}$. and urinary urobilinogen increased. Chloramphenicol was withheld, prednisone started, and a blood transfusion given the day after admission. The high fever which had been present dropped within 24 hours, the child felt well, and the haemoglobin rose to $8.5 \mathrm{~g}$. On the twentieth day of her illness she again became febrile and blood culture grew Salm. typhi, while the Widal test became positive to a titre of $1 / 200$ for $\mathrm{O}$ and $\mathrm{H}$ antigens. On

Clinical and Laboratory Data on 5 Patients with Typhoid Fever and Anaemia

\begin{tabular}{|c|c|c|c|c|c|c|c|c|c|c|c|c|c|}
\hline \multirow[b]{2}{*}{$\begin{array}{l}\text { Case } \\
\text { No. }\end{array}$} & \multirow[b]{2}{*}{$\begin{array}{l}\text { Age } \\
\text { and } \\
\text { Sex }\end{array}$} & \multirow[b]{2}{*}{$\begin{array}{l}\text { Ethnic } \\
\text { Group }\end{array}$} & \multicolumn{2}{|c|}{ Admission } & \multicolumn{6}{|c|}{ Acute Haemolysis } & \multirow{2}{*}{$\begin{array}{l}\text { Commencement of } \\
\text { Chloramphenicol } \\
\text { treatment. } \\
\text { Day of } \\
\text { Illness } \\
\end{array}$} & \multicolumn{2}{|c|}{ Follow-up } \\
\hline & & & $\begin{array}{l}\text { Day of } \\
\text { Illness }\end{array}$ & $\begin{array}{l}\mathrm{Hb} \\
\mathbf{g .} \%\end{array}$ & $\begin{array}{l}\text { Day of } \\
\text { Illness }\end{array}$ & $\begin{array}{l}\mathrm{Hb} \\
\mathbf{g} . \%\end{array}$ & $\begin{array}{c}\text { Reticu- } \\
\text { locytes } \\
\% \\
\end{array}$ & $\begin{array}{c}\text { Total } \\
\text { Bi irubin } \\
\text { mg. } / 100 \mathrm{ml} .\end{array}$ & $\begin{array}{l}\text { Osmotic } \\
\text { Fragility }\end{array}$ & $\begin{array}{l}\text { Coombs } \\
\text { Test }\end{array}$ & & $\begin{array}{c}\text { Days from } \\
\text { onset of } \\
\text { Illness }\end{array}$ & $\begin{array}{l}\mathrm{Hb} \\
\mathrm{g.} \%\end{array}$ \\
\hline $\begin{array}{l}1 \\
2 \\
3 \\
4 \\
5\end{array}$ & $\begin{array}{ll}5 & M \\
7 & M \\
3 & M \\
7 & M \\
8 & F\end{array}$ & $\begin{array}{l}\text { Yemenite } \\
\text { Iraqi" } \\
\text { Persian } \\
\text { Yemenite }\end{array}$ & $\begin{array}{c}3 \\
5 \\
7 \\
7 \\
10 \\
20 \\
\text { (relapse) }\end{array}$ & $\begin{array}{l}8.4 \\
9.8 \\
7.4 \\
9.5 \\
6.4 \\
8.5\end{array}$ & \begin{tabular}{r|}
9 \\
8 \\
10 \\
14 \\
20
\end{tabular} & $\begin{array}{l}5.9 \\
6.6 \\
4.7 \\
6 \\
5 \cdot 4\end{array}$ & $\begin{array}{r}7.8 \\
7.1 \\
17.0 \\
8.0 \\
0.8 \\
5.0\end{array}$ & $\begin{array}{l}\overline{1 \cdot 7} \\
\overline{1 \cdot 2} \\
1 \cdot 2 \\
-\end{array}$ & $\begin{array}{c}\text { Normal } \\
\text { ב } \\
\text { Normal }\end{array}$ & $\begin{array}{l}\text { Neg. } \\
", \\
\# \\
\#\end{array}$ & $\begin{array}{r}7 \\
9 \\
7 \\
10 \\
20\end{array}$ & $\begin{array}{l}45 \\
44 \\
23 \\
21 \\
57\end{array}$ & $\begin{array}{l}11 \cdot 8 \\
11 \cdot 4 \\
7.7 \\
10 \\
10.5\end{array}$ \\
\hline
\end{tabular}




\section{J. A. ARMSTRONG AND MARGUERITE S. PEREIRA: IDENTIFICATION OF "RYAN VIRUS"}

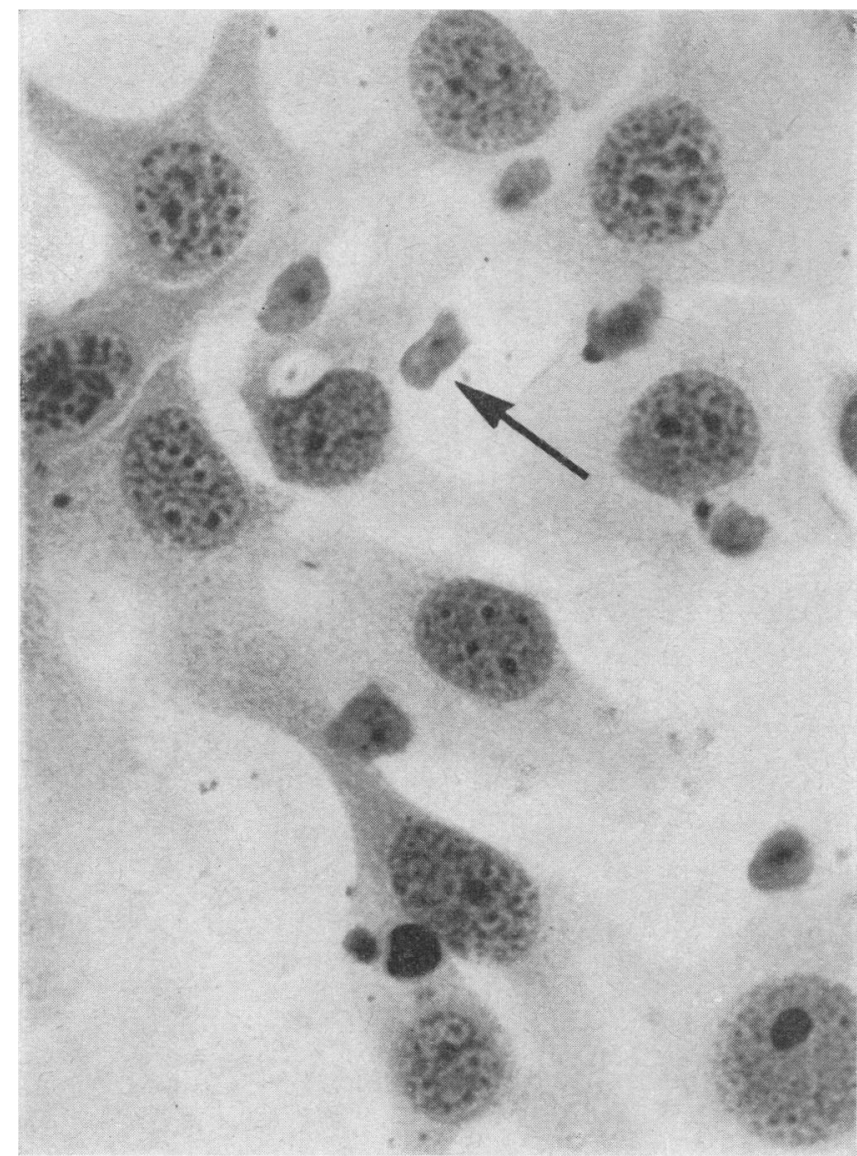

FIG. 1

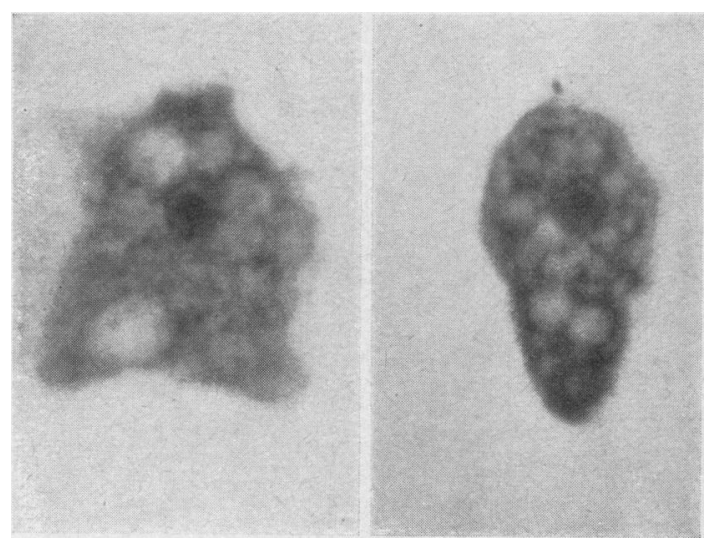

FIG. 2

FIG. 1.-48-hour-inoculated HeLa-cell culture, showing the appearance of amoebae (one of which is arrowed) at moderate magnification. ( $\times 550$.

FIG. 2.-High-power microscopical view of two hartmannellid amoebae as seen in an inoculated humanembryo-kidney-cell culture, showing the characteristic nuclear morphology and cytoplasmic vacuolation.

A. O. LANGLANDS $E T$ AL.: LYMPHADENOPATHY IN PATIENT RECEIVING PRIMIDONE

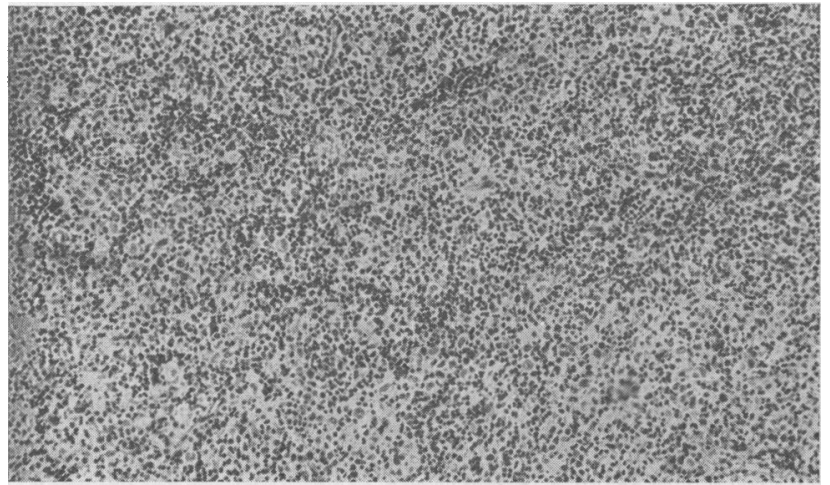

FIG. 1

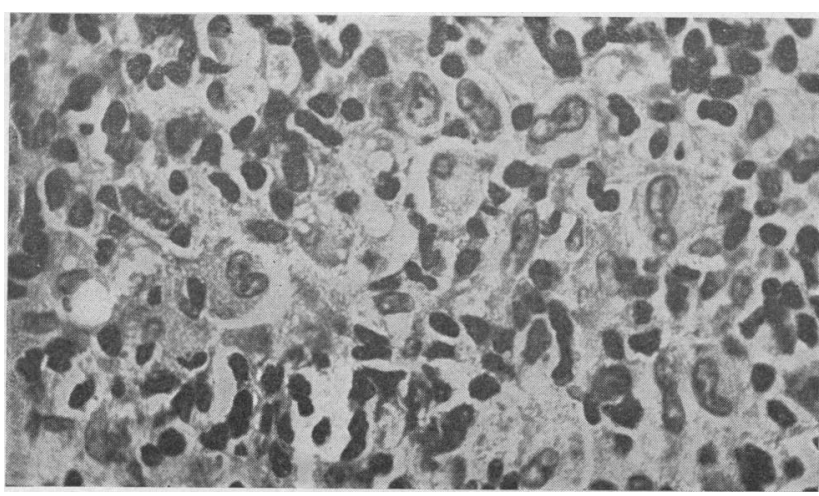

FIG. 2

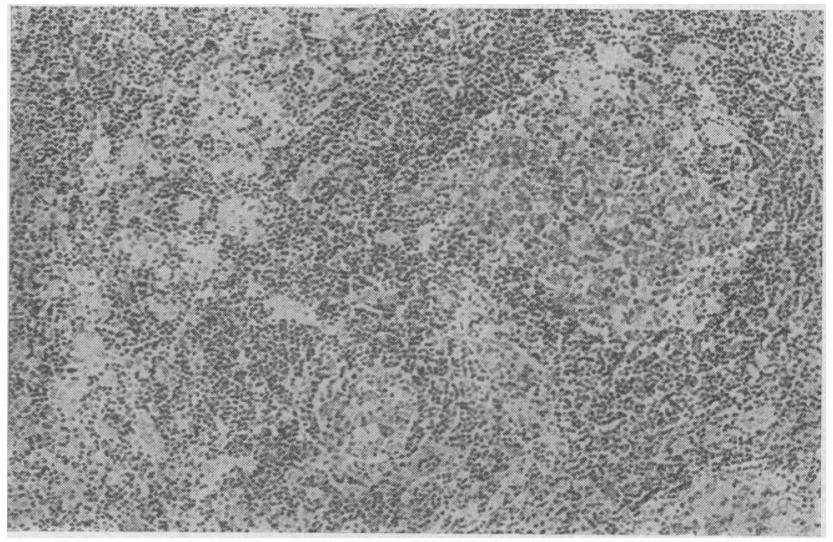

FIG. 3

FIG. 1.-Lymph node 7 October 1965, showing loss of norma architecture due to infiltration by abnormal reticulum cells. $(\times 69$.

FIG. 2.-Lymph node 7 October 1965, showing infiltration by abnormal and sometimes vacuolated reticulum cells. $(\times 345$.

Fig. 3.-Lymph node 10 December 1965 (five weeks after stopping primidone), showing partial return of follicular structure and decrease in number of abnormal reticulum cells. $(\times 69$. 